\title{
The kinship and affinal terminology of the Karesuando Lapps (Sámi) ${ }^{1}$
}

It is now some twenty-five years since the late Robert Pehrson and the present writer conducted social anthropological fieldwork among the Lapps (Sámi) ${ }^{2}$ of the northernmost Swedish Parish of Karesuando, respectively in the two administrative districts of Könkämä and Lainiovuoma. ${ }^{3}$ In the resulting doctoral theses, both of us have independently presented the kinship terminology then in use, as well as the 'classic' North Lappish system of which it was certainly a derivative. ${ }^{4}$ I

${ }^{1}$ I have to acknowledge the financial assistance of the Canada Council, who generously made me a research grant (no. S76-0646) to enable me to return to the field in 1977, as well as the liberal leave arrangements of my own institution, Simon Fraser University. I must also thank the numerous informants within Lainiovuoma who have allowed me to take up their time with what to some at least must have seemed boring questions, and especially my friends Per-Bertil and Anne Simma in whose hospitable home this article was first drafted. I am also indebted to my teacher and friend, Professor Knut Bergsland of the University of Oslo for several stimulating discussions, as well as detailed corrections of my manuscript.

${ }^{2}$ Since the preferred term for these people, Sámi or Saami, has not yet been widely accepted in English, I have retained the more familiar Lapp/Lappish, albeit with some hesitation.

${ }^{3}$ Karesuando is divided for administrative purposes into two districts, both of which follow the traditional migratory orientation of NW-SE; that lying adjacent to the international frontier with Finland takes its name from the river which forms the border, Könkämä (Lp. Gæeg'gan), whilst the other half, lying to the south and west, is known as Lainiovuoma (Lp. Láv'njitvuobmi).

4 In my book this forms a separate Appendix A "Lappish kinship terminology" (Whitaker 1955: 125-33); in Pehrson's monograph the material is essentially contained in two chapters, II and III, Pehrson 1957: especially 22-33, 47-54. 
have recently had a further spell of fieldwork in the same area, and am now able to report on subsequent modifications of the kinship terminology as it is used by the Lapps of Lainiovuoma. In this article I shall examine the changes that have been occurring over a period of some sixty years.

For many years now the Karesuando Lapps have tended to look to the linguistic usage of Kautokeino as representing a 'purer' form of Lappish than their own. This process may partly have been stimulated by scholars such as Konrad Nielsen, who has documented the Kautokeino dialect in both his grammar and his dictionary (Nielsen 1926-9, 1932-8), but also in recent years this has been accelerated by the access through radio to programmes emanating from Kautokeino, a more densely populated area. It should also be borne in mind that many Kautokeino Lapps emigrated to Karesuando after the closure in 1852 of the Norwegian-Russian frontier to reindeer nomads 5 and this certainly had some linguistic after-effects. It might also be mentioned that Könkämä in particular has retained close ties through marriage with Kautokeino, so that there was, for example, a whole band there in 1952, the members of which wore the characteristic Kautokeino dress, and also used a variety of Lappish strongly influenced by Kautokeino usage. ${ }^{6}$

Although there was no social anthropological study of Kautokeino at that time, so that the behaviour associated with particular kinship terms has largely gone unrecorded there, Nielsen's dictionary provides us with more than enough information to reconstruct the kinship terminology in use. This essentially 'dictionary' system I shall call the 'classic' terminology, and as we shall see, it underlay both Pehrson's and my own field analyses: this constitutes the baseline for the first 'phase' in this polychronic ${ }^{7}$ analysis; the second phase is

s For a discussion of this immigration, which I have termed the first Lappish diaspora. see Elbo 1952: especially 348-50, Whitaker 1955: 20-1.

${ }^{6} \mathrm{cf}$. Pehrson 1957: 81.

${ }^{7}$ A synchronic analysis is one conducted at one point in time, whereas a diachronic one essentially compares material collected from two different time-periods. I have coined the term polychronic to apply to an analysis in which material from more than two points in time is compared. 
documented by the field data included in our monographs, dating back to observations in 1952; the third phase is demonstrated by material collected in 1977 in Lainiovuoma only, but with a Könkämä-born informant included in my sources. I shall confine myself to discussing the terminology, and will not consider either the question of the appropriate behaviour between kinsmen of particular categories, or the interesting but complex question as to how the terminology might have evolved to the classic model in the first instance. Nor will I here take up the important comparative aspects invited by the work of Bergsland (1942) and Falkenberg (1953), from the southern Norwegian Lappish districts of Roros and Snåsa respectively. ${ }^{8}$

We must first distinguish between two important sociological concepts consanguinity and affinity. Consanguines are of the same blood, and form an individual's kindred (Lp. norm. såkkagad'di), who are sharply distinguished from one's affines (Lp. norm. dakkansågat), with whom one is connected by marriage. ${ }^{9}$ We shall first discuss the terms for consanguines polychronically, and then examine those for affines as they have changed over time.

We may first consider the terms for the elementary (nuclear) family, which Pehrson says (1957: 25) form a terminologically distinct unit, although it is not easy to see in which respects they are distinctive. ${ }^{10}$ There are separate terms for 'father', 'mo-

${ }^{8}$ I should also mention the general Finno-Ugrian analysis of Harva (1940. 1947), although in this essay I shall not take up the wider comparative questions.

${ }^{9}$ Pehrson gives both terms (1957: 21), as sokkâgod'de and dâkkânsokkât; in my citation of his manuscript I add (1955: 139) " = dâkkâm-sogot??" In 1977 I found the term dakkanskgat was well understood by my informants, as was the case with såkkagiddi, although this appeared less familiar.

I should observe that Pehrson and I used an orthography based on the work of Nielsen; for the data from 1977 I use the current internationally agreed orthography, now in the process of revision, but retain distinctive Karesuando features such as the plural in $-t$; where relevant $I$ have occasionally added in parentheses the modernized spelling to the earlier data, prefixed by "norm."

${ }^{10}$ Pehrson (1957: 25) deduces a general principle ('A') "Isolation of the three generational bilateral extended family". I cannot see in what respect he can 
ther', 'brother', 'sister', 'son' and 'daughter', as well as terms for 'parent' and 'child', whilst that for 'sibling' is generally lacking. ${ }^{11}$

\begin{tabular}{|c|c|c|c|c|}
\hline & Classic & $\begin{array}{l}\text { Könkämä } \\
1952\end{array}$ & $\begin{array}{l}\text { Lainiovuoma } \\
1952\end{array}$ & $\begin{array}{l}\text { Lainiovuoma } \\
1977\end{array}$ \\
\hline $\begin{array}{l}\text { father } \\
\text { referentially }\end{array}$ & $a \check{c}^{\prime} \dot{c} e$ & $a \check{c}^{\prime} \operatorname{cre}^{2}$ & $a \check{c} \check{c} e$ & $a ́ a c ́ c ̌ i$ \\
\hline $\begin{array}{c}\text { father } \\
\text { vocatively }\end{array}$ & $a c ̌ c ̌ e ~$ & $\begin{array}{l}\text { isä } \\
\text { 'very common' }\end{array}$ & isä & $\begin{array}{l}\text { isá } \\
\text { 'general' }\end{array}$ \\
\hline $\begin{array}{l}\text { mother } \\
\text { referentially }\end{array}$ & ced'ne & ad'ne & ad'ne & $c e d ' n i$ \\
\hline $\begin{array}{c}\text { mother } \\
\text { vocatively }\end{array}$ & ced'ne & $\begin{array}{l}\text { ete }{ }^{13} \\
\text { very common }\end{array}$ & äiti & $\begin{array}{l}\text { eide } \\
\text { 'general' }\end{array}$ \\
\hline brother & viel'ljâ & viel'ljâ & viel'ljâ & viel'lja \\
\hline sister & $o a b^{\prime} b a$ & $o a b^{\prime} b a$ & $o a b^{\prime} b a$ & $o a b^{\prime} b a ́$ \\
\hline son & bar'dne & bar'dne & bar'dne & bár'dni \\
\hline daughter & niei'dâ & niei'dâ & niei'dâ & niei'da \\
\hline $\begin{array}{l}\text { parents }{ }^{14} \\
\text { child }\end{array}$ & $\begin{array}{l}\text { vānhëmâk } \\
\text { manna }\end{array}$ & $\begin{array}{l}\text { vanhemât } \\
\text { manna }\end{array}$ & $\begin{array}{l}\text { vānhëmâk }{ }^{15} \\
\text { manna }\end{array}$ & $\begin{array}{l}\text { vánhemat } \\
\text { mánná }\end{array}$ \\
\hline
\end{tabular}

It should be noted that with the exception of the last two terms, all differentiate the sex of the person referred to (Pehrson's Principle 'B'). The distinction between the referential and vocative forms for 'father' and 'mother', in which the Finnish term is used in direct speech, is independently noted by both Pehrson and myself. ${ }^{16}$ Pehrson also records (1957: 25) the prefix

describe this as bilateral at this point: rather he would seem to be anticipating some of his later argument.

${ }^{11}$ Pehrson gives vielljaš or oabbaš as 'sibling' but this must be an error, perhaps the reciprocal forms from compounds such as vielljâš-guovtos 'brothers (mutually)'.

'2 Pehrson writes isa (1957: 25). I have described in another essay (Whitaker 1978) the posthumous publication of his monograph, following his death during subsequent fieldwork in Baluchistan. A note attached to the Preface says: "The departmental staff has seen the manuscript through its final processing"; this probably accounts for a number of minor typographical errors which would doubtless have been removed had the author lived.

${ }^{13}$ This is surely a Lappicization of äiti?

14 Neither Pehrson nor I record the singular form vánhen.

15 In retrospect I cannot believe that this is correctly recorded, as the Karesuando plural would end in $-t$. It may well be an example of the unconscious influence exerted on the fieldworker by Nielsen's dictionary.

16 Whitaker 1955: 128; Pehrson 1957: 25. 
bieb'mo- (Lp. 'nourishment') to indicate foster-relationships for foster-son and foster-daughter. I could add for Lainiovuoma 1977 bieb'moáč́či and bieb'moced'ni, 'foster-father' and 'foster-mother'. An additional modifier is the suffix -bcelle (Lp. 'half) which may be added to the six basic terms for members of the elementary family to indicate 'half'-relationships: i.e. where there is one common parent. ${ }^{17}$ Pehrson also records the term lii'vâš-manna (Lp. 'unattached child') for an illegitimate child. I did not publish any equivalent term, but collected in both 1952 and 1977 the form juol'gimánná (Lp.juol'gi 'leg'), which is to be compared with the local peasant (i.e. North Finnish) usage of jalkalapsi, with the same connotation.

We come now to the terms for 'cousin', in which it is important to note that no distinctions are made as to whether they are related to the speaker through either his father or his mother: in the anthropological jargon, the system displays total bilaterality, the same term being used to designate 'father's brother's son', 'father's sister's son', 'mother's brother's son' and 'mother's sister's son', with another term applying to the daughter of one's parent's male or female sibling. Pehrson places great emphasis on the cousin terms, and indeed states (1957: 23):

" '. . the Lappish concept of cousinhood is one of the keys to Lappish social structure...'

The North Lappish terms for cousin are as follows:

\begin{tabular}{|c|c|c|c|c|}
\hline & Classic & $\begin{array}{l}\text { Könkämä } \\
1952\end{array}$ & $\begin{array}{l}\text { Lainiovuoma } \\
1952\end{array}$ & $\begin{array}{l}\text { Lainiovuoma } \\
1977\end{array}$ \\
\hline $\begin{array}{l}\text { male first } \\
\text { cousin }\end{array}$ & vilj-bcellĕ & $\begin{array}{l}\text { vilj-bcelle } \\
\text { or bcelle }{ }^{18}\end{array}$ & vilj-bcelle & $\begin{array}{l}\text { bcel'la }{ }^{18} \\
\text { (viljbcelli } \\
\text { occasionally) }\end{array}$ \\
\hline $\begin{array}{l}\text { female first } \\
\text { cousin }\end{array}$ & oam-bcellĕ & $\begin{array}{l}\text { oam-bcelle } \\
\text { or bcelle }^{18}\end{array}$ & oam-bcellë & $\begin{array}{l}\text { bcel'la }^{18} \\
\text { (oambcelli } \\
\text { occasionally) }\end{array}$ \\
\hline
\end{tabular}

${ }^{17}$ In Lainiovuoma I note (1955: 128) that the suffix is often omitted in speech, by which I think I meant it was not used vocatively.

${ }^{18}$ This shortened form was used by speakers under 30 years old in 1952 . I did not record any shortened form in Lainiovuoma in 1952 but by 1977 it was general. 
Pehrson sees (1957: 29) the fuller terms as hypocristic forms of 'half-brother' and 'half-sister', respectively viel'lja-bcelle and $o a b^{\prime} b a$-bcelle, and derives a principle (' $F$ ') equating siblings and cousins, but I have elsewhere implied (Whitaker 1960) that this equation is less than total. ${ }^{19}$

For the term used between the children of first cousins (i.e. 'second cousins'), Pehrson records the use of the prefix nubbe(Lp. 'second'): nubbe-vilj-bcelle - one may presuppose also nubbe-oam-bcelle. In Lainiovuoma in 1952 I found the same terms, although I comment (1955: 129) that more frequently the terms huol'ke (classic Lappish fuol'ke 'kinsman') and næeppe, which in the classic system had the meaning of 'son or daughter of a man's sister or of his female first cousin' were used in direct speech. Pehrson also recorded the term gol'bma-vilj-balle (Lp. goalmád- 'third') as a reciprocal term used between the great-grandchildren of siblings, but my informants in Lainiovuoma in 1952 would either use huol'ke, or more commonly olmai (norm. ålmai 'friend' and especially 'herding companion' with an implication of closeness), or use a circumlocution incorporating the term lakka-såkka (Lp. lakka 'near', såkka 'kin'). ${ }^{20}$

We may now move to the first ascending generation, which in addition to differentiating both the sex and generation of the person referred to, also distinguishes the father's and mother's sides, and if the kinsman is of the same sex as the parent through

${ }^{19}$ Although this article is not concerned with the behavior expected between kinsmen, I should perhaps record that I found on a number of occasions in Lainiovuoma in 1977 that a special link exists between first cousins of the same sex, who, in given instances, displayed behaviour that was comparable with that expected between siblings of the same sex.

${ }^{20}$ Johan Turi, the classical Lappish author, who was born in Kautokeino in 1853 , but moved in 1857 to Karesuando, and later to Jukkasjärvi, where he spent the greater part of his life, uses this term in his second book, Fran fjället (Thuri 1931: 109), which Nesheim (1942: 5) has described as being written in a more typical Jukkasjärvi dialect. Turi writes "soai leika koapašat mu lahga sokat" "they were both my near relatives": in the normalised orthography "soai leiga goabbašagat mu lakka sågat". This would be typical of the current Lainiovuoma usage, which avoids specifying the precise relationship of kinsmen more distant than first cousins. 
whom the relationship is traced, also his/her relative age (Pehrson's principles 'B', 'C' and 'D').

\begin{tabular}{|c|c|c|c|c|}
\hline & Classic & $\begin{array}{l}\text { Könkämä } \\
1952\end{array}$ & $\begin{array}{l}\text { Lainiovuoma } \\
1952\end{array}$ & $\begin{array}{l}\text { Lainiovuoma } \\
1977\end{array}$ \\
\hline $\begin{array}{l}\text { father's elder } \\
\text { brother }\end{array}$ & cekke & $\begin{array}{l}\text { akke or } \\
\text { cacce } 21\end{array}$ & $\begin{array}{l}\text { čæcce } 22 \text { 'almost } \\
\text { universally' }\end{array}$ & crecci \\
\hline $\begin{array}{l}\text { farher's elder male } \\
\text { first cousin } 23\end{array}$ & akke & $\begin{array}{l}\text { cekke or } \\
\text { crecce }^{21}\end{array}$ & $\begin{array}{l}\text { črecce } 22 \text { 'almost } \\
\text { universally' }\end{array}$ & - \\
\hline $\begin{array}{l}\text { father's younger } \\
\text { brother }\end{array}$ & čacce & cacce & $\check{c} a c c e^{22}$ & caeci \\
\hline $\begin{array}{l}\text { father's younger } \\
\text { male first cousin } 23\end{array}$ & črecce & cacce & čecce 22 & - \\
\hline father's sister & siessa & siessa & siessa & siessá \\
\hline $\begin{array}{l}\text { father's female } \\
\text { first cousin } 23\end{array}$ & siessa & siessa & siessa & - \\
\hline $\begin{array}{l}\text { mother's elder } \\
\text { sister }\end{array}$ & goas'ke & $\begin{array}{l}\text { goas'ke or } \\
\text { muossa } 21\end{array}$ & muotta 24 & muottá \\
\hline $\begin{array}{l}\text { mother's elder } \\
\text { female first cousin }{ }^{23}\end{array}$ & goas'ke & $\begin{array}{l}\text { goas'ke or } \\
\text { muossa } 21\end{array}$ & muotta $^{24}$ & - \\
\hline $\begin{array}{l}\text { mother's younger } \\
\text { sister }\end{array}$ & muotta & moussa ${ }^{24}$ & muotta $^{24}$ & muottá \\
\hline $\begin{array}{l}\text { mother's younger } \\
\text { female first cousin } 23\end{array}$ & muotta & moussa ${ }^{24}$ & muotta $^{24}$ & - \\
\hline mother's brother & èno & $\bar{a}$ no & ano & ano \\
\hline $\begin{array}{l}\text { mother's male first } \\
\text { cousin } 23\end{array}$ & äno & $\overline{\text { Ceno }}$ & ceno & - \\
\hline
\end{tabular}

The classic terminology for kinsmen in the first descending generation also makes a relative age distinction, if the kinsman's

${ }^{21}$ Pehrson records (1957: 27) that fifteen out of twenty informants in Könkämä ignore relative age distinctions in the parental generation both referentially and vocatively. Thus ccece is used three times as frequently as akke, and muossa similarly more often than goas'ke when referring respectively to 'father's elder brother' and 'mother's elder sister'. I record (1955: 128) that "... čcecce was almost universally used even when referring to persons properly designated in the classic system as akke, although older persons recognized this latter term even if they did not use it. The term for mother's elder sister, goas'ke, seems to have disappeared entirely."

${ }^{22}$ Pehrson records that the classic Lappish initial $\check{c}$ becomes $c$ in Könkämä usage; I did not make this annotation in 1952, but certainly this is also the case in Lainiovuoma in 1977 , and one is forced to conclude this was also so in 1952; perhaps this is another instance of the influence the dictionary has on the fieldworker. This has been drawn to my attention by Professor Knut Bergsland.

23 'first cousin' should here be taken to imply bilateral calculation. 
parent is a sibling or cousin of the same sex as the speaker. This is as follows:

\begin{tabular}{|c|c|c|c|c|}
\hline & Classic & $\begin{array}{l}\text { Könkämä } \\
1952\end{array}$ & $\begin{array}{l}\text { Lainiovuoma } \\
1952\end{array}$ & $\begin{array}{l}\text { Lainiovuoma } \\
1977\end{array}$ \\
\hline $\begin{array}{l}\text { son or daughter of } \\
\text { a man's younger } \\
\text { brother }\end{array}$ & cekkeb & $\begin{array}{l}\text { akket or caccet } 25 \\
\text { or vielljâ-bar'dnel } \\
\text { vielljâ-nieida }\end{array}$ & $\begin{array}{l}\text { čcceb }{ }^{26} \text { or } \\
\text { vielljâ-bar'dnel } \\
\text { vielljâ-niei'dâ }\end{array}$ & $\begin{array}{l}\text { viellja-bárdnil } \\
\text { viellja-nieida }\end{array}$ \\
\hline $\begin{array}{l}\text { son or daughter of } \\
\text { a man's younger } \\
\text { male first cousin } 23\end{array}$ & cekkeb & $\begin{array}{l}\text { akket or caccet } 25 \\
\text { or vilj-balle-bar'dnel } \\
\text { vilj-balle-niei'dá }{ }^{27}\end{array}$ & $\begin{array}{l}\text { čacceb }{ }^{26} \text { or } \\
\text { vilj-balle-bardnel } \\
\text { vilj-balle-niei'dá }\end{array}$ & - \\
\hline $\begin{array}{l}\text { son or daughter of } \\
\text { a man's elder } \\
\text { brother }\end{array}$ & čacceb & $\begin{array}{l}\text { caccet or } \\
\text { vielljâ-bardnel } \\
\text { vielljâ-nieidâ }\end{array}$ & $\begin{array}{l}\text { čacceb or } \\
\text { vielljâ-bar'dnel } \\
\text { vielljâ-niei'dî }\end{array}$ & $\begin{array}{l}\text { viellja-bár'dnil } \\
\text { vielljâ-nieida }\end{array}$ \\
\hline $\begin{array}{l}\text { son or daughter of } \\
\text { a man's elder male } \\
\text { first cousin } 23\end{array}$ & $\check{c} c e c c e b$ & $\begin{array}{l}\text { caccet or } \\
\text { vilj-balle-bardnel } \\
\text { vilj-balle-nieidat } 27\end{array}$ & $\begin{array}{l}\text { cacceb }{ }^{26} \text { or } \\
\text { vilj-balle-bardnel } \\
\text { vilj-balle-nieidâ }{ }^{28}\end{array}$ & - \\
\hline $\begin{array}{l}\text { son or daughter of } \\
\text { a woman's brother }\end{array}$ & siessâl & $\begin{array}{l}\text { siessâl or } \\
\text { vielljâa-bar dnel } \\
\text { vielljâ-nieidâ }\end{array}$ & $\begin{array}{l}\text { siessâl or } \\
\text { vielljâ-bardnel } \\
\text { viellja-nieidâ }\end{array}$ & $\begin{array}{l}\text { viellja-bár'dnil } \\
\text { vielljâ-niei'da }\end{array}$ \\
\hline $\begin{array}{l}\text { son or daughter of } \\
\text { a woman's male } \\
\text { first cousin } \\
23\end{array}$ & siessâl & $\begin{array}{l}\text { siessâl or } \\
\text { vilj-bcelle-baridnel } \\
\text { vilj-bcelle-nieidata }\end{array}$ & $\begin{array}{l}\text { siessâl or } \\
\text { vilj-balle-bardnel } \\
\text { vilj-balle-nieidât }\end{array}$ & oabba-bär'dnil \\
\hline $\begin{array}{l}\text { son or daughter of } \\
\text { a woman's younger } \\
\text { sister }\end{array}$ & goas'keb & $\begin{array}{l}\text { goasket or muossâl } 23 \\
\text { or oabba-bardnel } \\
\text { oabba-nieidâ }\end{array}$ & $\begin{array}{l}\text { muottäl } 29 \text { or } \\
\text { oabba-bar'dnel } \\
\text { oabba-niei'dá }\end{array}$ & oabba-niei'da \\
\hline $\begin{array}{l}\text { son or daughter of } \\
\text { a woman's younger } \\
\text { female first cousin } 2.3\end{array}$ & goas keb & $\begin{array}{l}\text { goasket or muossal }{ }^{25} \\
\text { or oam-balle-bardnel } \\
\text { oam-balle-niei dá }{ }^{27}\end{array}$ & $\begin{array}{l}\text { muotfäl } 29 \text { or } \\
\text { oam-bcelle-bardnel } \\
\text { oam-bcelle-nieidá } 28\end{array}$ & - \\
\hline
\end{tabular}

24 Pehrson writes muossa, whilst 1 write muotta in the text, although my diagram shows the correct muotta. The absence of this character in most printers' typeface is a good reason for its abolition.

${ }^{25}$ As with the terms for 'father's brother' and 'mother's sister', three out of every four informants ignored the relative age distinctions in Könkämä in 1952; thus creccet is preferred to cekket, and muossâl to goas'ket.

26 Again I have written in 1952 crecceb, whereas the usage may have been coeccit.

27 Pehrson merely says (1957: 26)". . . similar descriptive compounds for children of cousins"; I have inferred that these were the forms used.

${ }^{28}$ I did not record these terms for Lainiovuoma in 1952, but they must be assumed to have been used; the terms are purely descriptive, but the relationships may have been designated by an alternative term such as huol'ke; after this lapse of time I cannot be quite certain. It should be observed that there are no special terms in use in present-day Lainiovuoma for these categories.

29 I have written muottal, although the correct orthography at that time was muottal. The term is thus written on my kinship diagram. 


\begin{tabular}{|c|c|c|c|c|}
\hline & Classic & $\begin{array}{l}\text { Könkämä } \\
1952\end{array}$ & $\begin{array}{l}\text { Lainiovuoma } \\
1952\end{array}$ & $\begin{array}{l}\text { Lainiovuoma } \\
1977\end{array}$ \\
\hline $\begin{array}{l}\text { son or daughter of } \\
\text { a woman's elder } \\
\text { sister }\end{array}$ & muorràl & $\begin{array}{l}\text { muossal or } \\
\text { oabba-bardnel } \\
\text { oabba-nieidâ }\end{array}$ & $\begin{array}{l}\text { muortal }{ }^{29} \text { or } \\
\text { oabba-bardnel } \\
\text { oabba-nieida }\end{array}$ & $\begin{array}{l}\text { oabba-bárdnil } \\
\text { oabba-nieida }\end{array}$ \\
\hline $\begin{array}{l}\text { son or daughter of } \\
\text { a woman's elder } \\
\text { female first cousin }{ }^{23}\end{array}$ & muortail & $\begin{array}{l}\text { muossâl or } \\
\text { oam-balle-bardnel } \\
\text { oam-balle-nieida } 27\end{array}$ & $\begin{array}{l}\text { muotral }{ }^{29} \text { or } \\
\text { oam-balle-bar'dnel } \\
\text { oam-balle-nieidá }{ }^{28}\end{array}$ & - \\
\hline $\begin{array}{l}\text { son or daughter of } \\
\text { a man's sister }\end{array}$ & nceppe & $\begin{array}{l}\text { nappe or } \\
\text { oabba-bar'dnel } \\
\text { oabba-nieidâ }\end{array}$ & $\begin{array}{l}\text { nceppe or } \\
\text { oabba-bar'dnel } \\
\text { oabba-niei'da }\end{array}$ & $\begin{array}{l}\text { oabba-bárdnil } \\
\text { oabba-nieidda }\end{array}$ \\
\hline $\begin{array}{l}\text { son or daughter of } \\
\text { a man's female first } \\
\text { cousin } 23\end{array}$ & nappe & $\begin{array}{l}\text { nceppe or } \\
\text { oam-bcelle-bardnel } \\
\text { oam-boelle-nieida }{ }^{27}\end{array}$ & $\begin{array}{l}\text { nceppe or } \\
\text { oam-bcelle-bardnel } \\
\text { oam-bcelle-nieida } 28\end{array}$ & - \\
\hline
\end{tabular}

We come now to the terms for second ascending and second descending generations. In the case of the older generations, persons are distinguished according to their sex, but there is only one term for 'grandfather' and the 'brother of the speaker's grandparents' on the one hand, and 'grandmother' and the 'sister of the speaker's grandparents' on the other: the system is thus truly bilateral. In the second descending generation kinsmen are categorised according to the sex of the speaker:

\begin{tabular}{|c|c|c|c|c|}
\hline & Classic & $\begin{array}{l}\text { Könkämä } \\
1952\end{array}$ & $\begin{array}{l}\text { Lainiovuoma } \\
1952\end{array}$ & $\begin{array}{l}\text { Lainiovuoma } \\
1977\end{array}$ \\
\hline grandfather ${ }^{30}$ & $a g^{\prime} g j a$ & $\begin{array}{l}\text { ag'gja or } \\
\text { faari }\end{array}$ & $a g^{\prime} g j a$ & ád'djá \\
\hline $\begin{array}{l}\text { brother of } \\
\text { any grand- } \\
\text { parent }\end{array}$ & {$\left[a g^{\prime} g j a\right]^{31}$} & $\begin{array}{l}\text { ag'gja or } \\
\text { faari- } \\
\text { viel'ljâ }\end{array}$ & $a g^{\prime} g j a$ & $\begin{array}{l}\text { ád'djá } \\
\text { 'occasionally' }\end{array}$ \\
\hline grandmother ${ }^{30}$ & $a k^{\prime} k o$ & $\begin{array}{l}\text { ak'ko or } \\
\text { muori }\end{array}$ & $a k^{\prime} k o$ & $a^{\prime} k^{\prime} k o$ \\
\hline $\begin{array}{l}\text { sister of } \\
\text { any grand- }\end{array}$ & {$\left[a k^{\prime} k o\right]^{31}$} & $\begin{array}{l}a k^{\prime} k o \text { or } \\
\text { faari-oab ba } a^{32}\end{array}$ & $a k^{\prime} k o$ & $\begin{array}{l}a ́ k^{\prime} k o \\
\text { 'occasionally' }\end{array}$ \\
\hline
\end{tabular}

${ }^{30}$ (bilateral).

${ }^{31}$ This meaning is not given in Nielsen's dictionary (1932-8), but is inferred to have had that sense also in the classic terminology.

${ }^{32}$ This term is inferred from Pehrson 1957: 29; one may also infer muori-viel'ljâ and muori-oab'ba. 


\begin{tabular}{|c|c|c|c|c|}
\hline & Classic & $\begin{array}{l}\text { Könkämä } \\
1952\end{array}$ & $\begin{array}{l}\text { Lainiovuoma } \\
1952\end{array}$ & $\begin{array}{l}\text { Lainiovuoma } \\
1977\end{array}$ \\
\hline $\begin{array}{l}\text { a man's } \\
\text { grandchild (of } \\
\text { either sex) }\end{array}$ & $a g^{\prime} g j o b$ & $\begin{array}{l}\text { ag'gjot or } \\
\text { bardne-bar'dnel } \\
\text { nieidâ-bar'dnel } \\
\text { bardne-niei'dàl } \\
\text { nieidâ-niei'dâ }{ }^{33}\end{array}$ & $a g^{\prime} g j o b$ & $\begin{array}{l}\text { bárdne-bár'dnil } \\
\text { nieida-bár'dnil } \\
\text { bárdne-niei'dal } \\
\text { nieida-niei'da }\end{array}$ \\
\hline $\begin{array}{l}\text { grandchild of } \\
\text { either sex of } \\
\text { a man's } \\
\text { siblings }\end{array}$ & {$\left[a g^{\prime} g j o b\right]^{31}$} & $a g^{\prime}$ gjot & $a g^{\prime} g j o b$ & - \\
\hline $\begin{array}{l}\text { a woman's } \\
\text { grandchild } \\
\text { (of either } \\
\text { sex) }\end{array}$ & $a k^{\prime} k o b$ & $\begin{array}{l}\text { ak'kot or } \\
\text { bardne-bar'dnel } \\
\text { nieida-bar'dnel } \\
\text { bardne-niei'dâl } \\
\text { nieida-niei'dâ }\end{array}$ & $a k^{\prime} k o b$ & $\begin{array}{l}\text { bárdne-bár'dnil } \\
\text { nieida-bár'dnil } \\
\text { bárdne-niei'dal } \\
\text { nieida-niei'da }\end{array}$ \\
\hline $\begin{array}{l}\text { grandchild of } \\
\text { either sex of } \\
\text { a woman's } \\
\text { siblings }\end{array}$ & {$\left[a k^{\prime} k o b\right]^{31}$} & $a k^{\prime} k o t$ & $a k^{\prime} k a b$ & - \\
\hline
\end{tabular}

This completes the consanguineal terminology, with the exception of the terms for great-grandparents. Here the prefix māddâr- (norm. máddar- 'root') is used. One of Pehrson's informants, Nils' Anni ${ }^{34}$, is quoted as saying (Pehrson 1975: 21):

"At the bottom, under the ground in the same way that tree roots are under the ground, are the great-grandparents and further back. These are the māddâr relatives. As the tree trunk raises above the ground so come the grandparents and parents and parents' siblings. Higher up am I and my siblings. Still higher as the trunk gets narrower are my children and my children's children. The siblings of my great-grandparents or the siblings of their parents form joints (Lp. buol'vât) ${ }^{35}$ at the side of the trunk. From them come my third and fourth cousins far off from me at the top of the tree ... But not many know their fourth cousins"'.

Another Könkämä Lapp, Lalli's Jon ${ }^{36}$, said:

${ }^{33}$ Only bardne-bar'dne is given, but the others may be inferred.

${ }^{34}$ i.e. Lp. Niilas' An'ni, Anna Hotti (née Siiri), born in Kautokeino in 1912, and now deceased - information from Anne Simma; cf. Pehrson 1953: 254.

${ }^{35}$ recte buolvât.

${ }^{36}$ i.e. Lp. Lalli-Jouna, Jon Larsson Hotti, born in Könkämä - information from Anne Simma. 
"The fourth generation (Lp. buol'va) is the boundary of consanguinity. The fifth generation is as a draft reindeer" [i.e. gelding - not creating kin]. ${ }^{37}$

In Lainiovuoma I have not had such picturesque discussion, and the terms $m \bar{a} d d \hat{a} r-a g^{\prime} g j a$ and $m \bar{a} d d a \hat{r}$ - $a k^{\prime} k o$ - respectively, great-grandfather and great-grandmother - were not used, although my informants recognized them. ${ }^{38}$

The consanguineal terminology I have depicted has clearly been undergoing significant changes. In the first instance we may speak of a 'shrinkage' of the total kinship network, as identified by a specific terminology - compare Charts I and II. Whereas one's parents' first cousins were grouped with one's parents' siblings in 1952, this usage had disappeared by 1977 . In the same way the children of a speaker's cousins are no longer included in the terminology. Grandparent's siblings seem still to be included, ${ }^{39}$ but the grandchildren of one's siblings have similarly dropped out. This process of shrinkage seems to have been already evident in 1952 with the adoption of descriptive compounds, such as bardne-bar'dne.

This example, however, also documents another process that can be detected in the terminology: the gradual substitution of generic by descriptive terms which spell out the precise relationship. Here I think one can detect the influence of the Swedish kinship terminology, where 'brother's son' ( $\mathrm{Sw}$. brorson) is distinguished from 'sister's son' (Sw. systerson), and similarly for daughters. This second trend, for which I have coined the somewhat barbaric term 'descriptivisation', is most apparent in referring to generations younger than that of the speaker. For the adjacent older generation there has occurred a process of reduction of the categories by the disappearance of the relative age distinctions. Both these two latter trends were

\footnotetext{
37 Pehrson 1957: 23.

38 Whitaker 1955: 129.

${ }^{39}$ This was complicated by the fact that $a g^{\prime} g j a$ was used as a generic term for 'old man', and $a k$ 'ko similarly for 'old woman' - cf. Pehrson 1957: 29.
} 


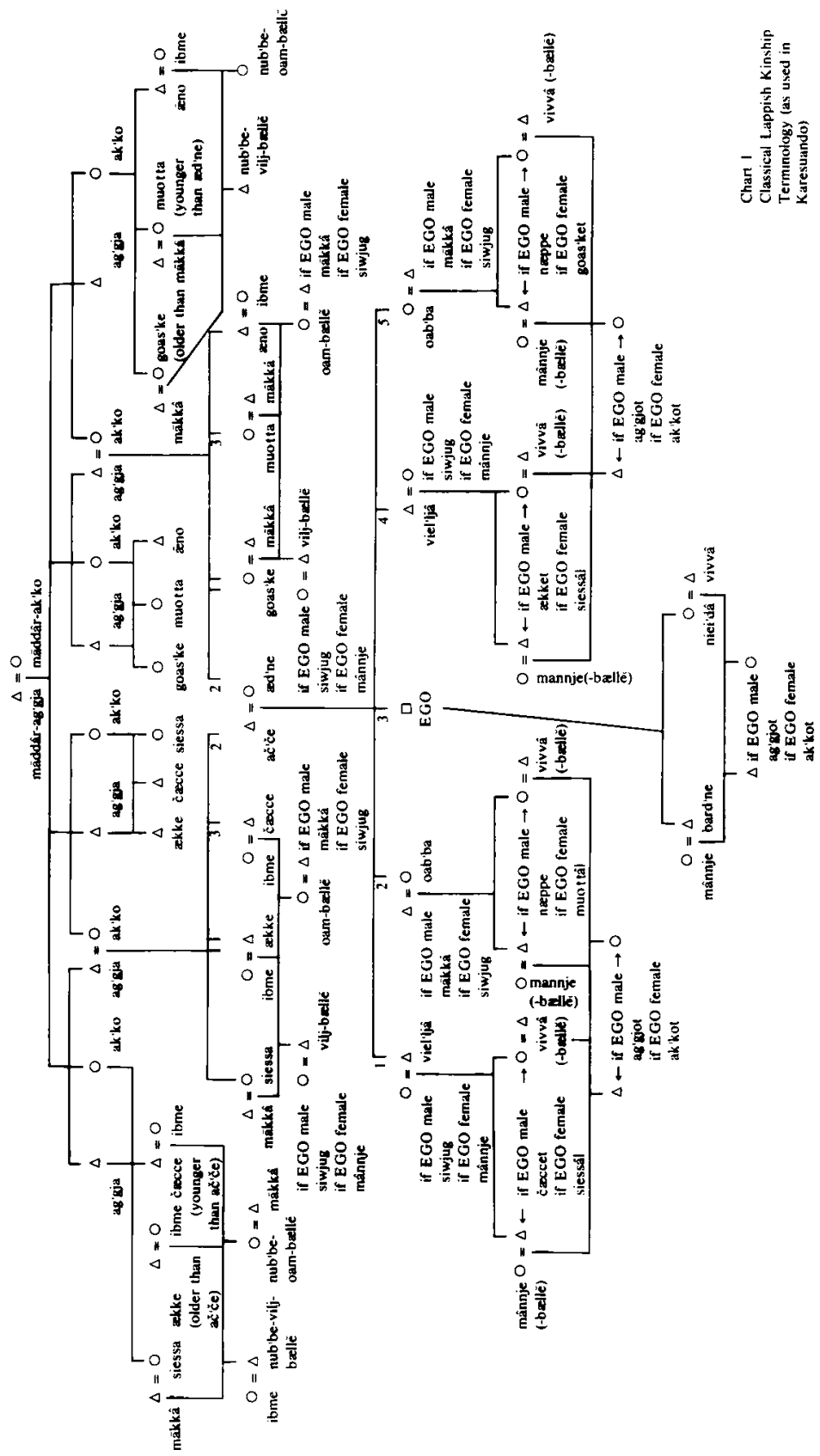




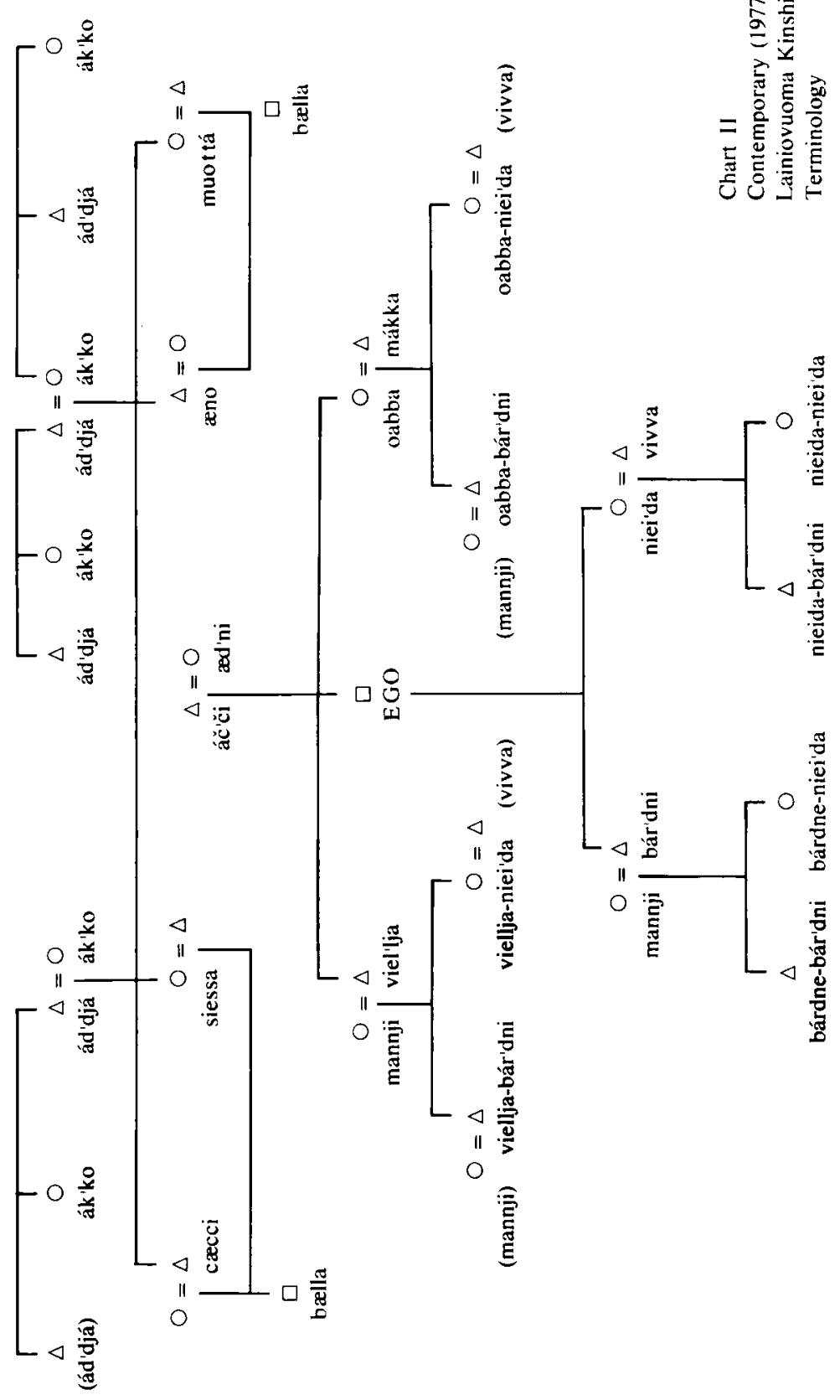


already in evidence in Lainiovuoma in 1952, but the process has gone much further by 1977 . On the other hand, Könkämä in 1952 represented in most respects a system closer to that of the classic system - the only exceptions were in the terms for grandparents and grandchildren, where terms loaned from Finnish had begun to intrude, as well as the emergence of descriptivised terms which were not recorded from Lainiovuoma for those kinship categories at that date. The age-distinctions for the adjacent senior generation were more readily used in Könkämä than in Lainiovuoma in 1952. In the case of the cousin-terms, there has been a change in the other direction, the sex of the person referred to being no longer indicated.

It is noteworthy that the only changes in the terminology as it affects those closest to the speaker - members of his elementary family - are the adoption of Finnish terms when addressing 'father' and 'mother'; but this trend has not gone further in the time-interval. One other process may be alluded to: the gradual disappearance of reciprocal or nearly-reciprocal terms. This is well illustrated in the terms used respectively by a grandchild to his/her grandfather, $a g^{\prime} g j a$, and the term he would use in reply, $a g$ 'gjob. The classic terminology has seven pairs of such terms: ag'gjalag'gjob, ak'kolak'kob, cekke/cekkeb, čreccelčrecceb, siessalsiessâl, goas'kelgoas'keb, muottalmuottâl; only the čno/nceppe terms do not fit this pattern. (However, the classic cousin terms are also based on the sex of the person referred to, rather than that of the speaker, and they may therefore not be identical.) These seven pairs in the classic terminology are reduced to five in Lainiovuoma in 1952 (through the disappearance of cekke and goas'ke) and three of them might be descriptivised; by 1977 none of these reciprocal paired terms are complete, and descriptivisation has become universal in denoting the younger relatives. However in the contrary direction a new symmetrically reciprocal pair has emerged, bcel'la/bcl'la, perhaps again by analogy with the Swedish system, where a common term for cousin ( $\mathrm{Sw}$. kusin) contradicts the general pattern of descriptive terms, and does not differentiate the sexes.

Pehrson has an additional principle ('E') which he calls the 
"partial equation of alternate generations". This allegedly operates by linking, for example, the person a speaker calls čece with the person he calls čacceb - that is to say EGO's father's younger brother is linked to EGO's elder brother's son. I very much doubt if in practice this link would be perceived by the two persons concerned, who in any case would stand in an $a g$ 'gjalag'gjob relationship to each other. ${ }^{40}$

$* * *$

We come now to the affinal terminology: i.e. the terms used by a speaker to indicate those persons to whom he is related by marriage rather than by blood. We need not delay with the terms boad'nje 'husband', and cem'me 'wife', although galles (norm. gállis 'old man') might be used for the former in Lainiovuoma. There are seven terminological categories of affines. It is significant however, that in 1952 the classic [i.e. dictionary] system was completely retained for affinal terms in both Könkämä and Lainiovuoma. I shall therefore discuss the terms seriatim, indicating subsequently what changes have occurred in respect of the usage in Lainiovuoma in 1977.

I shall initially deal with terms connoting a person of a different generation from the speaker. First we may consider those who have married into one's own kindred, i.e. the spouses of one's parents' siblings:

mäkkâ ${ }^{41}$ One's father's or mother's sister's husband, or the husband of one's parent's female first cousin

ibme One's father's or mother's brother's wife, or the wife of one's parent's male first cousin

The more distant relationships are no longer indicated by these terms in Lainiovuoma. Next follow the terms for the spouses of one's children:

vivvâ son-in-law

mânnje daughter-in-law

${ }^{40} \mathrm{cf}$. Pehrson 1957: 27-9. Others fall in the category $a k^{\prime} k o / a k^{\prime} k o b$. He is however wrong in speaking $(1957: 28)$ of four logical possibilities: there are six.

${ }^{41}$ Pehrson gives makkâ: the distinction is a minor one. 


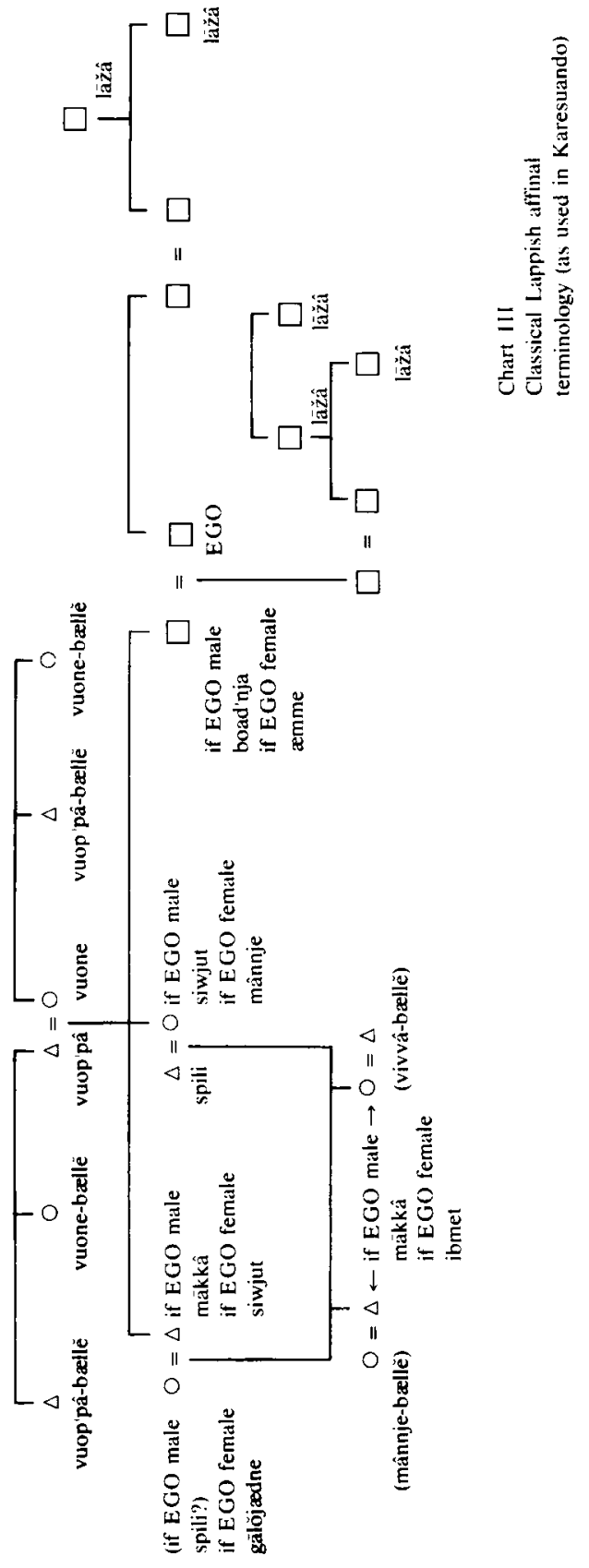


The terms vivvâ-bcelle and mânnje-balle were recorded in 1952 as denoting respectively men and women who have married more distant members of one's kindred, or to combine step-relationships and affinity, ${ }^{42}$ but they are not used in 1977 . However vivvâ and mânnje are generally used today, although as we shall see mânnje has several meanings. Next we may consider those who are one's spouse's kindred:

\section{vuop'pâ father-in-law vuone mother-in-law}

In 1952 I also gave the following terms, now no longer used: vuop'pâ-bcelle EGO's spouse's stepfather; EGO's spouse's father's (or mother's) brother or male first cousin; EGO's spouse's father's (or mother's) sister's (or female first cousin's) wife.

vuone-bcelle EGO's spouse's stepmother; EGO's spouse's father's (or mother's) sister or female first cousin; EGO's spouse's father's (or mother's) brother's (or male first cousin's) wife.

These are clearly also dictionary-based definitions. ${ }^{43}$ Two

42 I gave the following definitions (1955: 131):

vivvâ-bcelle: EGO's stepdaughter's husband; EGO's brother's (or sister's or male or female first cousin's) daughter's husband: EGO's spouse's brother's (or sister's or male or female first cousin's) daughter's husband [i.e. one's spouse's vivvâ].

mânnje-balle: EGO's stepson's wife; EGO's brother's (or sister's or male or female first cousin's) son's wife; EGO's spouse's brother's (or sister's or male or female first cousin's) son's wife [i.e. one's spouse's mânnje ].

These are clearly dictionary-derived meanings, not obtained in this form by field inquiry. Pehrson's discussion (1957: 49) is shorter:

"By adding -bcelle, these terms may be extended to include more distant affines of Ego's kindred or a combination of step-relationship and affinity. Thus mânnje-bcelle designates cousin's sons's wife, grandson's wife or stepson's wife."

The extension to the alternate descending generation is not included in my data.

${ }^{43}$ Pehrson says of vuop'pa and vuome (1957: 49):

"'By adding the suffix -bcelle, "half," these terms may be extended to embrace spouse's parental siblings and cousins. Such compounds may also designate a "step" relationship. Thus vuop'pâ-bœlle designates spouse's parental male siblings or cousins, spouse's parental female siblings (sic!) or 
further terms denote one's spouse's kindred, albeit of the younger generation: ${ }^{44}$

$m a \bar{k} k \hat{a}^{41}$ son or daughter of one's wife's brother or sister, or of her male or female first cousin

$i b m e b^{45}$ son or daughter of one's husband's brother or sister, or of his male or female first cousin

These terms clearly depend upon the sex of the speaker, but form reciprocal pairs with makkka and $i b m e$ discussed above. Thus we may speak of mākkâlmäkkâ and ibme/ibmeb pairs. The extension to spouse's cousin's children does not now occur.

We must next discuss the terms for affines of one's own generation, which present some complexity: they may be divided into affines connected through one marriage tie, and those more distantly related through two marriages:

$m a \bar{k} k \hat{a}^{41}$ a man's sister's (or female first cousin's) husband; ${ }^{46}$ one's wife's brother or male first cousin: i.e. both categories of a man's 'brother-in-law'. 47

mânnje ${ }^{48}$ a woman's brother's (or male first cousin's) wife ${ }^{46}$

cousin's husband and spouse's step-father." He surely here means 'sibling's' since the term does not denote women.

${ }^{44}$ In my book (1955: 131) I mistakenly write "'(b) persons who have married into EGO's own kin-group - younger generation" instead of "(b) persons who have married into EGO's spouse's kin-group - younger generation"; similarly "(d) persons of EGO's spouse's kin-group - younger generation" should read "(d) persons of EGO's kin-group - younger generation".

${ }^{45}$ Pehrson records (1957: 49) ibmet for Könkämä; I suspect the same usage in Lainiovuoma at that time.

${ }^{46}$ In the kinship diagram attached to my book (1955: 126, Fig. 17) the terms for EGO's cousins' spouses, differentiated according to the sex of the speaker, have been accidentally juxtaposed by the draughtsman. The written text is correct.

47 Pehrson does not specifically show this first meaning for Könkämä, which is not included in his discussion.

${ }^{48}$ In my textual discussion (1955: 131) I say that mânnje may also be used to denote one's husband's brother's (or male first cousin's) wife - a person related through two marnages. My diagram (p. 130, Fig. 18) shows this person designated by the term spili, whilst Pehrson (1957: 50, Chart VI) shows the same person designated by the term gälöjcedne. After 25 years I cannot sort out this muddle, which illustrates the intricacy of kinship analysis: it is probably due to conflicting information collected in the field. 
her husband's sister or female first cousin: i.e. both categories of a woman's 'sister-in-law' ${ }^{47}$

siwjug $^{49}$ a man's brother's (or male first cousin's) wife; ${ }^{46}$ or his wife's sister or female first cousin - i.e. both categories of his 'sister-in-law'; a woman's sister's (or female first cousin's) husband, ${ }^{46}$ or her husband's brother or male first cousin - i.e. both categories of a woman's 'brother-in-law'.

It will be seen that these terms form symmetrical pairs mäkkâlmäkkâ, mânnje/mânnje and siwjug/siwjug, the first two being restricted to people of the same sex, whilst the latter is used between speakers of the opposite sex.

Two terms denoting people related through two marriages occurred in the classic terminology:

gälöjcedne probably ${ }^{50}$ a woman's husband's brother's (or his male cousin's) wife.

spili one's wife's sister's (or brother's) spouse, one's husband's sister's (or brother's) spouse. ${ }^{51}$

If correctly defined both of these terms form reciprocal pairs, gälöjcednelgälöjcedne being restricted to female speakers, whilst spili/spili may refer to people of either sex. One final, and somewhat complex, term remains to be discussed:

lāža One's son's (or daughter's) parents-in-law; one's brother's (or sister's) parents-in-law; one's son-in-law's (or daughter-in-law's) sibling; one's brother's (or sister's) spouse's sibling; one's son's (or daughter's) parentin-law's sibling.

49 In Lainiovuoma in 1977 this term, although little used, has become siwjut; it may have had that phonetic form in 1952.

${ }^{\text {so }}$ My description (1955: 132) is clearly wrong. I have deduced this classic form from Pehrson's diagram (1957: 50, Chart VI) since he neglects to define the relationship in words. However, my definition contradicts my own diagram. since I there show a woman's husband's brother's wife as spili. The first cousin extension I separately define as galojarn-bcelle, which I admit having taken from Bergsland 1942: 156, as it was not used in Lainiovuoma.

${ }^{51}$ This definition does not quite coincide with that in my book (1955: 132), being slightly broader. Pehrson (1957: 49) specifically challenges Nielsen's dictionary definition (1932-8: 541), but his own diagrams do not show all his categories. My earlier diagram does however meet this definition. 
As Pehrson remarks (1957: 54) the lažâ term ignores both sex and generation. ${ }^{52}$

We can detect similar principles in operation in the classic affinal terminology to those in the consanguineal vocabulary. With the exception of läža, mākk $\hat{a}$ and mânnje the terms indicate the generation of the person referred to, and in general the sex of the person referred to. The same tendency to equate siblings and cousins that Pehrson has recorded in the classic consanguineal terminology is demonstrated in the classic affinal terms; however the relative age distinctions of the former system are missing from the affinal terminology. Instead of the distinctions between father's kindred and mother's kindred, we have the separation of those who have married into one's own kindred from those who have married into one's spouse's kindred, although this is not complete. Both mäkkâ and mânnje disturb the symmetry, which leads Pehrson to conclude (1957: 53):

"'Thus, these terms do not lend themselves to structural-functional analysis and may best be correlated with an earlier terminological situation." 53

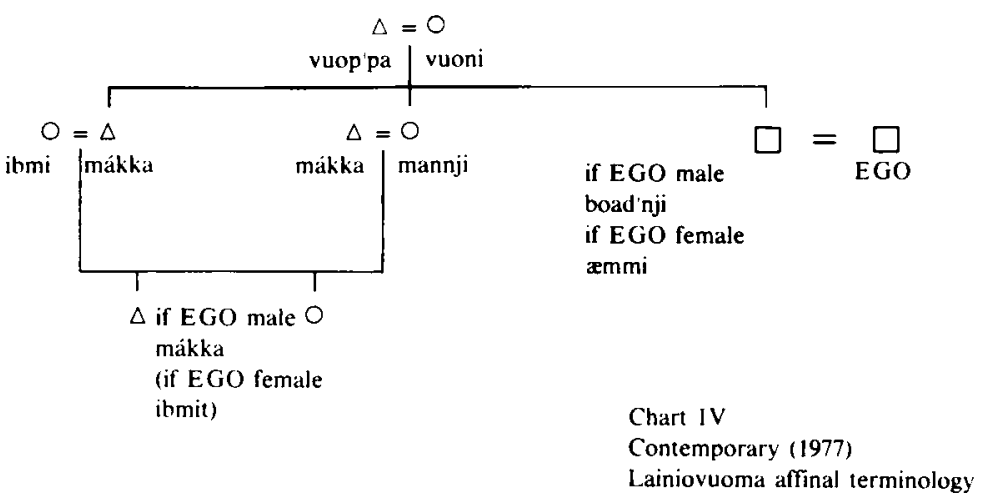

\$2 I record (1955: 132) an additional use of lažâ: ". . . as a reciprocal term between the parents of a rân'gâ [hired herder] and the rän'gâ's employers ..." I remember that my informant was particularly emphatic about this usage.

${ }^{53}$ I am reluctant to use the suggestion of historical survival to explain the incongruity of these terms, but they certainly do not seem to accord with any single organizing principle. 
We must now consider the contemporary usage for affinal terms in Lainiovuoma. We can first distinguish six affinal categories corresponding to those of the elementary family: vuop'pa 'father-in-law', vuoni 'mother-in-law' and vivva 'sonin-law' present no problems. For 'daughter-in-law', mannji, there is already some confusion, since the term may be used in other senses, and a few of my informants said they would use a descriptive term bárdne-cemmi. For 'brother-in-law' mákka seemed generally used, whilst for 'sister-in-law' some would use mannji, whilst others would prefer descriptive terms such as viellja-cemmi 'brother's wife' or cemmi-oab'bá 'wife's sister'. Siwjut was not generally used, and often not understood.

To indicate the 'spouse of one's parent's sibling' two terms differentiating by sex seem to be used, mákka and $i b m i$, but the former gives rise to some doubt in the minds of my informants, and the descriptive compounds siessa-boad'nji, muotta-boad'$n j i$ are sometimes preferred. For the first descending generation of affines, one's spouse's siblings' children, or one's own siblings' children's spouses, it would seem that descriptive compounds are almost universally used. Gálujcedne, spile and láža are all unused, and largely uncomprehended, although in the case of older informants they will be associated with affinity in some vague way. The fact that mákka and mannji have wider connotations seemed to be known to my informants, but they could not be precise. The only exception to this general ignorance of the classic affinal system was a Könkämä-born informant who had married into Lainiovuoma. If she is typical one might presume that many of the traditional terms still retain their meaning and usage in Könkämä, but time and circumstance precluded my investigating the situation outside Lainiovuoma.

In summarizing the contemporary situation in respect of the affinal terminology we may say that the same general processes apparent in that relating to consanguines are evident: a shrinkage of the system was already apparent in Lainiovuoma in 1952, with some of the usage which Pehrson reports from Könkämä in respect of equating siblings and cousins affinally having already passed out of use; by 1977 the realistic boundaries of affinity 
exclude cousins in the ascending and descending generation compare Charts III and IV. There has been a general trend towards what I have termed 'descriptivisation'. Paired terms have also disappeared, except that mákka may be used between male affines of approximately the same age.

I have hitherto treated the terminology as if there were uniform usage in a given place at a given time. This is not, however, the case: in reality individual speakers are spread along a continuum, the polar points of which may be demarcated by the terms 'conservative' and 'innovatory'. The members of the same sibling group tend to be clustered together on this continuum, although there is often one member of a sibling group who is pinpointed as 'knowledgeable' in such matters which may often be synonymous with 'conservative'. An incoming spouse may establish a new usage for her children, but will rarely change her husband. ${ }^{54}$ Until recent years Lainiovuoma males tended to find their wives locally; now however a number of wives have moved into the community from more distant Lappish groups, but it is yet too soon to see whether this will have any lasting effect on the terminology. It must also be admitted, however, that the fieldworker may have unconsciously over-estimated the retention of the classic system in 1952. In this respect the pre-existence of Nielsen's dictionary has had some influence.

Pehrson, however, has described (1957: 20) his method of working, and this is, perhaps, worth quoting in extenso:

"'The data on terminology was obtained through the usual genealogical method, by hearing the terms spoken in daily life or by eliciting them if genealogical connections were already known from Karesuando Parish archives. Complete kinship schedules were obtained from six informants: three men, aged twenty-two, thirty-six, and forty-six, all born in Könkämä and three women, one aged thirty-nine and born in Könkämä, the other two aged thirty-six and thirty-nine and born in Kautokei-

\footnotetext{
54 I consciously treat the incoming spouse as female, as there are still no cases of men joining Lainiovuoma upon their marriage to Lainiovuoma women.
} 
no. Fourteen incomplete schedules were obtained from eight men (aged ten to seventy-one, two born in Lainiovuoma, one in Kautokeino, the remainder in Könkämä) and six women (aged twelve to sixty-seven, one born in Eno[n]tekis, the rest in Könkämä). In addition to these twenty schedules, every articulate Lapp I questioned - an age range of three to eighty-three provided fragments of kinship information. After each session with the six main informants - these sessions being spread over a period of some weeks because of the often fast tempo of Lappish life which allows little time for formal interviewing - I constructed charts of the elicited terms in order to understand the logic of the terminology as a conceptual scheme and to anticipate gaps in the informant's circle of kin. If the Lapp had no relative who would be able to fill a gap in the emerging abstract chart of Könkämä kinship, I would anticipate what the term might be according to the logic of the system and the pose a kinship conundrum such as "If Karin's Lars (the informant's mo. Br. So. [mother's brother's son D) was married and had a son what would you call him and he you?" Every time I did this the informant immediately gave a term correct according to the logic of the system indicating that he too was aware of his system as a system."

This lengthy but excellent description should prove a model for subsequent social anthropologists. However one might criticise Pehrson on two grounds: firstly he may have had too many informants linked with Kautokeino, if indeed there was a distinction between the usage in Karesuando and that in Kautokeino. Secondly his main informants all fall within a limited age-range: 22 to 46 . It should be noted that the kinship terminology provides the central focus of the discussion in his thesis.

My own methodology has not been described, and does not meet these high standards. Much of my terminological material was collected from two or three key informants, ${ }^{55}$ including two men born in Lainiovuoma, in 1895 and 1911, and a woman born in the same community in 1923; thus in 1952 their age range was from 57 to 29 . However the focus of my study was not on the terminology per se, and I was concerned with the practical

ss Principally those persons listed in Appendix B of my book (1955: 134-8) as, respectively, 123, 111 and 95 . 
effects of kinship on behaviour (which led me to draw up genealogical schedules for all the inhabitants of the community). ${ }^{56}$ It is not, therefore, accidental that I discuss the terms in a separate appendix, rather than in the body of my study. My own treatment of the terminology owes much to Nielsen's dictionary. I believe Pehrson was similarly influenced, although not at all to the same extent.

One further aspect of kinship usage requires mention: how it is utilized in everyday conversation. Once again Pehrson has a full discussion (1957: 32-3):

"Terminological usage derives from generational differentiation. Children and youths up to the time when they join the regular herding force (usually at the age of about sixteen) address all kinsmen - both consanguineal and affinal - of ascending generations by the kinship term alone. Collateral kinsmen of ascending generations with whom one regularly herds may be addressed by the personal name compounded with the kinship term as one gets older, but parents and lineal grandparents are always addressed by kinship term alone. In speaking to kinsmen of one's own generation and age group, one uses personal names or a compound of personal name and kinship term: "Will Lars Johan-Male Cousin eat fish? Will Nils-My Male Affine (makkâ) drink coffee?" In addressing much younger members of descending kinship generations one almost always uses only the personal name. These are not consciously formulated rules but customary usages as I overheard them in the course of daily life. It is to be noted that there is a distinction between kinship generation and age group. The latter is not a formal age set but an informal classification embracing persons whose age coincides within about a twenty year period. Since generational kinship age may not correspond to actual age, two Lapps may have to choose whether to address each other by kinship terms or personal names. In cases where two Lapps belong to different age groups but the same kinship generation they will generally use the kinship term. Thus two male cousins, aged fifteen and fifty, always address each other as "'male cousin." If two Lapps belong to the same age group but different kinship generations, they generally use personal

56 cf. ibid.: 43. 
terms vocatively rather than the kinship term (but will qualify the personal name with the proper term when speaking referentially). Thus a sister's daughter aged thirty-nine addressed her mother's half-sister aged thirty-five by personal name (their relationship was further complicated by the fact that the two women were married to two male cousins and could have used an affinal term)."

The classic Kautokeino practice in the nineteenth century has been described in the memoirs of Anders Pedersen Bær (1825-82) who wrote (1926: 57, 1958: 69-70):

"The Lapps are generally fond of kinship and reckon as kinsmen even the fourth and fifth generations, as far back as one can remember. A Lapp never calls anyone other than his own children by their Christian name, but he uses both kinship term and Christian name whenever there is a kin-relationship, however distant."

I have stated (1955: 53) that this also applied in Lainiovuoma in 1952.

By 1977, when the terms consisted of descriptive compounds they were not in use vocatively. It is perhaps not irrelevant that it is the terms for the younger generation that tend to be descriptivised, and it may be that the use in direct speech of the older forms referring to persons of the ascending generation senior to the speaker has assisted in their preservation. Thus I have found that persons addressing an older relative today will still use a kinship term together with the name. ${ }^{57}$ In a few cases an incorrect term may be used, and it may be of interest to describe two such instances, as they show the kinship terminology in actual use.

In one instance (Fig. 1) an unmarried bachelor A (born in 1911) has insisted that his nephew B's children (C, D and E)

57 The recent proliferation of Christian names, including combinations of two names, among younger people in Lainiovuoma has also made it possible to distinguish individuals fairly precisely without additional 'identifiers' such as kinship terms. It cannot be entirely excluded that one factor contributing in the past retention of the kin-term as a suffix to the Christian name was the need to particularise people in a community with a relatively restricted number of names in general use; for a study of Lainiovuoma colloquial naming see Whitaker 1977. 


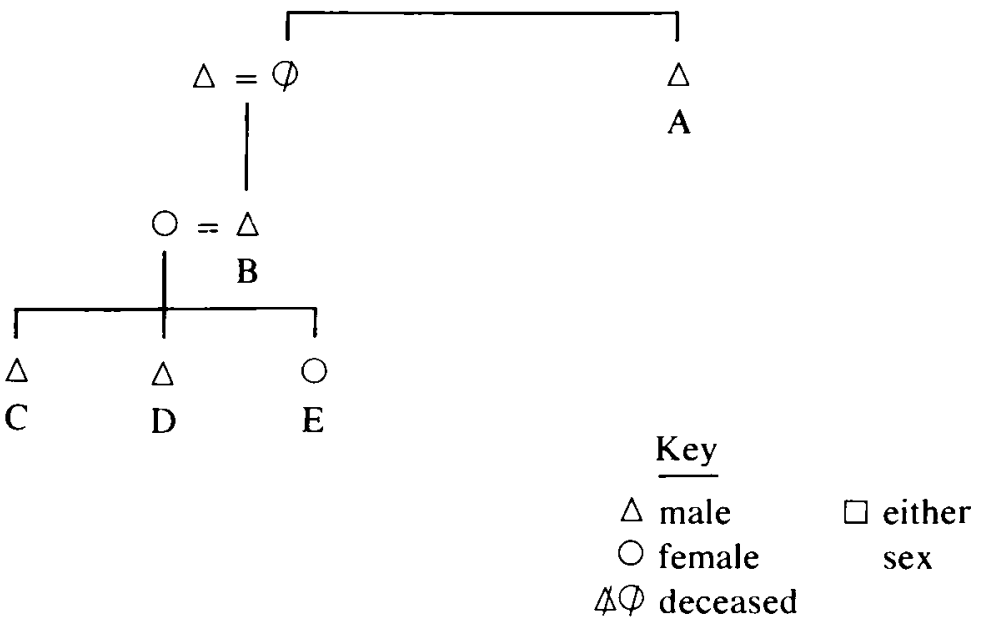

Fig. 1

should continue to use the same term as their father uses, namely ceno, although correctly they should call him ad'dja; with its additional connotations of 'old man' this is felt by him to be too aging. In another example (Fig. 2), a woman $\mathbf{M}$ (born in 1923) calls her husband's younger brother $L$ (born in 1927) by his Christian name with the suffix -ceeci, which is the same form correctly used by her son $\mathrm{N}$. In this case the usage is referential rather than vocative; however the situation is complicated by the fact that both $\mathrm{L}$ and $\mathrm{N}$ share the same Christian names. In the classic terminology she should use the suffix -siwjug, but as we have seen this has disappeared in contemporary Lainiovuoma. The alternative compounded form, boadnji-viel'lja is clearly too cumbersome, so she resorts to the term used by her son.

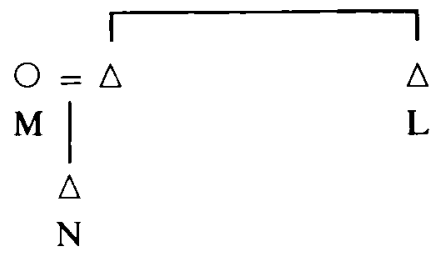

Fig. 2 
Two more instances show adherence to the 'rules' in somewhat unusual circumstances. In the simpler case (Fig. 3) we have two brothers $F$ and $G$ born respectively in 1928 and 1932 . Their much older half-brother $E$ (born 1895) has a son $H$ who was also born in 1928. Thus $H$ and $F$ are exactly the same age, and $H$ is four years older than $G$. When they were younger the boys used simple Christian names, but now $\mathrm{H}$ uses the term crecci (often, but not invariably, appended to the Christian name) when addressing his half-uncles, and when speaking of them to a third party always appends the kinship term to their Christian names. ${ }^{58}$

In my final example (Fig. 4), we have a complex situation where a man and a woman, $Q$ and $P$ both long deceased, had both had children by earlier marriages before they married each other. The woman P's daughter R (born 1916) later married the man Q's eldest son S (born 1905), also now dead, some years after $P$ and $Q$ had married and had a further son, $U$ (born 1923). Much later the half-brothers $T$ (who was born in 1914) and $U$ married two sisters, and the marriage of the elder half-brother resulted in children (W). The marriage of $R$ and $S$ also resulted in children (V), but that of $U$ proved childless. We come now to

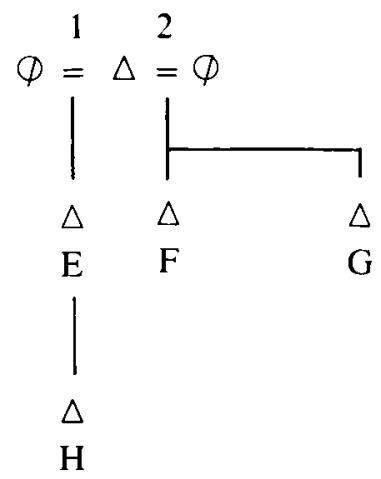

Fig. 3

s8 I have noted above (footnote 18) that the suffix -bcelle, which would be required according to classic usage, is not now retained. This particular case is referred to in Whitaker 1960: 143. 


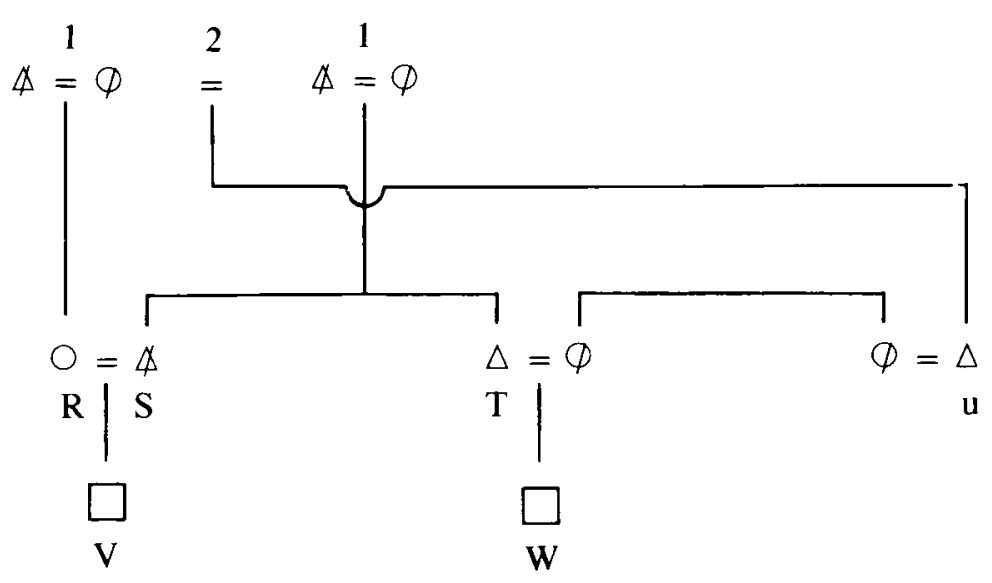

Fig. 4

the terms used by the people in this complicated kin-grouping when referring to each other. $S$ and $T$ (full brothers) and $U$ (their half-brother) all used the term viel'lja when speaking of each other. $\mathrm{R}$ and $\mathrm{S}$, who were not related by blood, although step-siblings, married many years before I arrived, so I do not know what terms they used before their union. $\mathrm{R}$ used the term viel'lja to refer to her halfbrother $\mathrm{U}$, but when speaking of $\mathrm{T}$, to whom she was not related by blood (also her step-brother), rather than using the 'correct' affinal term (siwjut) would speak of her husband's brother (boadnji-viel'lja). On the other hand U speaking of $S$ would use the term viel'lja, and of $\mathrm{R}$ would say $o a b ' b a$, which might leave an outsider with the impression of an incestuous marriage. To the next generation, $\mathrm{V}$ and $\mathrm{W}$, the eldest members of which were born in 1932 and 1940 respectively, $\mathrm{U}$ is known as cecci. Logically he could also be called by $\mathrm{V}$ ceno, since he is their mother's (half) brother. Since $\mathrm{T}$ and $\mathrm{U}$ have also married sisters $U$ also stands in the relationship of mákka to $\mathrm{W}$, but this is not used. Lastly $\mathrm{T}$ and $\mathrm{U}$ could theoretically also call each other by the mutual spile (but, of course, this gives way to the closer term viel'lja). From examples such as this one could draw up an order of preferred terms where people stand in more than one kin or affinal 
relationship to each other. The "decay" of the classic system makes such an exercise of purely academic interest.

In summary I would point out that the kinship and affinal terminologies of the Karesuando Lapps have shown marked change over a period of about sixty years. If we take the classic 'dictionary' terminology documented by Nielsen as our first phase, it is clear that this must refer to a system which had reached its high point around the turn of the century at the latest. When Pehrson went to Könkämä in 1952 the classic system was already being seriously modified for kinsmen, although the affinal terminology remained intact. ${ }^{59}$ It is possible, however, that the process of change was somewhat retarded there by inter-marriage with Kautokeino. In Lainiovuoma in 1952 my main informant, born in 1895, could describe the classic system with reasonable accuracy, but shrinkage was in evidence. He was clearly a somewhat 'conservative' informant, and elsewhere in the same community the trend towards descriptivisation was apparent, and was documented in my published account. Twenty-five years later the descriptivisation process is much more advanced, and many of the classic affinal terms have disappeared, whilst the kin terms are also changing.

We see, therefore, that a kinship terminology is not an abstract and unchanging entity, but is as malleable and dynamic as language itself. Just as, in the course of fieldwork, one will find some speakers who use archaic forms, and others who are innovative, so in a given community the kinship terminology varies. Whilst one might in particular collect material from the more conservative speakers, so that a particular usage does not go unrecorded, if one wishes to present a total picture one must seek to represent the whole continuum, rather than a single model, which might not actually coincide with any single

59 This leads Pehrson to pose the interesting question (1957: 69n) whether affinal and consanguineal terminologies change at differential rates, and if so, why? 
speaker's precise usage. As we have seen, the analytical task is not simple. ${ }^{60}$

IAN WHITAKER

\section{REFERENCES}

Bær, Anders Pedersen 1926. "'Erindringer 1828-1849 (Bidrag til Finmarkens kirkehistorie IV)", Norvegia Sacra Vol. VI: 40-79. Oslo.

— 1958. [Mui'talus] in Lars Jakobsen Hætta \& Anders Pedersen Bær:

"Mui talusat Guov'dagæino dilálašvuo daid birra åvdal d.j. 1850", Studia Septentrionalia Vol. VII: 40-102. Oslo.

Barth, Fredrik 1966. "Preface" to Robert N. Pehrson: The social organization of the Marri Baluch (Viking Fund Publications in Anthropology No. XLIII) Ed. Fredrik Barth): vii-xii. New York.

Bergsland. Knut 1942. "Det samiske slektskaps- og svogerskapsordsystem", Norsk Tidsskrift for Sprogvidenskap Vol. XIII: 148-98. Oslo.

Elbo, J. G. 1952. 'Lapp reindeer movements across the frontiers of northern Scandinavia", Polar Record Vol. VI: 348-58. Cambridge.

Falkenberg, Johannes 1953. "Slektskapssystemet hos Snåsa-samene”, Liber scecularis in honorem J. Qvigstadii Vol. II (Studia Septentrionalia Vol. V): 69-86. Oslo.

Goodenough, Ward H. 1964. "Componential analysis of Könkämä Lapp kinship terminology" in Ward H. Goodenough (ed.): Explorations in cultural anthropology: essays in honor of George Peter Murdock: 221-38. New York: McGraw-Hill.

Harva, Uno 1940. "Der Bau des Verwandtschaftsnamensystems und die Verwandtschaftsverhältnisse bei den Finno-ugriern" Finnisch-ugrische Forschungen Vol. XXVI: 91-120. Helsinki.

${ }^{60} 1$ have chosen to use the traditional EGO-based technique for analysing Lappish kinship, although the componential approach pioneered by Goodenough has much to recommend it. particularly in the case of the Lapps where such idiosyncrasies as the developed form of cardinal numerals -guovtos (cf. Nielsen 1926-9: Vol. I: $112 \$ 114)$ present interesting variations. Pehrson was aware of the need for a move away from an EGO-based analysis, as Barth recognizes (1966: xii) in his 'Preface' to his edition of Pehrson's posthumous field notes from the Marri Baluch:

"... I have felt justified in making some use of the formal scheme of componential analysis, since Pehrson's own analytical efforts in Lappish kinship (Pehrson, 1957) have an early affinity to this later development ..."

In the event Goodenough has completed a componential analysis (1964) based on Pehrson's data from Könkämä. 
1947. "The Finno-Ugric system of relationship", Transactions of the Westermarck Society Vol. I: 52-74. Copenhagen.

Nesheim. Asbjörn 1942. Der lappische Dualis (Skrifter utgitt av Det Norske Videnskaps-Akademi i Oslo II Hist.-Filos. klasse 1941 No. 5). Oslo.

Nielsen, Konrad 1926-9. Larebok i Lappisk 3 vols. Oslo: Brogger. 1932-8. Lappisk ordbok - Lapp dictionary (Instituttet for Sammenlignende Kulturforskning Series A Vol. XVII Nos. 1-3) 3 vols. Oslo.

Pehrson, Robert N. 1953. "Siida 1 at autumn residence, October 1951" in Ernst Manker: The nomadism of the Swedish mountain Lapps: the siidas and their migratory routes in 1945 (Acta Lapponica Vol. VII) (trans. Robert N. Pehrson): 254-6. Stockholm.

1957. The bilateral network of social relations in Könkämä Lapp District (Indiana University Publications Slavic and East European Series Vol. V). Bloomington.

Thuri, Johan 1931. Från fjället. Lund: Gleerup.

Whitaker, Ian 1955. Social relations in a nomadic Lappish community (Samiske Samlinger Vol. II). Oslo.

1960. "First cousinhood among the Northern Lapps", Folkloristica: festskrift till Dag Strömbäck 13. 8. 1960 (Saga och Sed 1959): 142-6. Uppsala.

1977. "Colloquial naming among the Lainiovuoma Lapps (Sámi)" Suomalais-ugrilaisen Seuran Aikakauskirja Vol. LXXV: 45-54. Helsinki. 1978. "The personal equation in fieldwork: an assessment of the work of Robert N. Pehrson (1926-1955)" Arctic Anthropology Vol. XV: 36-57. Madison. 